\title{
Constructions of Europe in English and German Picture Books
}

\author{
Susan Tebbutt
}

W hile there is much talk at the beginning of the twenty-first century of the importance of greater mutual understanding among member countries of the European Union, the reality seems less positive. As Julian Huxley, A.C. Haddon and A.M. CarrSaunders wrote in 1935 in We Europeans: A Survey of 'Racial' Problems: 'it is a matter of observation that passion thrives on ignorance and that dogmatic certitude is a pathetic attempt to find a substitute for patient knowledge, which is always humbly conscious of its inevitable limitations' (1935, p.7). 'Yet dogmatism is hard to dislodge. In a recent poll almost fifty per cent of British people expressed their hostility or indifference to membership of the EU, which the UK joined over twenty years previously. ${ }^{2}$ Do images of Europe presented in English and Germanlanguage picture books since the war do anything to promote a greater understanding of Europe?

My theoretical framework is constructed along two axes, the vertical being based on an amalgam of Homi Bhabha's Nation and Narration (1990) and John Stephens' Language and ldeology in Children's Fiction (1992), and the horizontal axis based on Perry Nodelman's Words and Pictures (1988).

The concept of nationhood is explored by Homi Bhabha in Nation and Narration. He argues: 'Nations, like narratives, lose their origins in the myths of time and only fully realize their horizons in the mind's eye' (Bhabha 1990, p. 1). Can we catch sight of nations within Europe in English and German-language picture books, or do we have to rely on our mind's eye? Bhabha is particularly interested in the ambivalence of language and also the ambivalence of the nation and its representation in literature and sees the cultural boundaries of the nation as fluid: 'The "locality" of national culture is neither unified nor unitary in relation to itself, nor must it be seen as "other" in relation to what is outside or beyond it' (1990, p.4).

But is it possible to convey this sense of fluidity in a picture book? When images of a specific European country, city or region are featured, are they stereotypical or thought-provoking? With reference to some dozen works in the English and German languages I explore the relationships between words, pictures and projections of nationality, making reference to Stephens' work on the ideologies of children's fiction, and his analyses of the ways in which writers seek to mould audience attitudes into 'desirable' forms. Since ideology may appear as an overt or explicit element of a text it will operate at the level of the story and its significance.

Any analysis of picture books must involve a mixture of semiotics, aesthetic evaluation and cultural awareness. As 'Nodelman argues in Words and Pictures, 'Because the words and the pictures in picture books both define and amplify each other, neither is as open-ended as either would be on its own' (1988, p.viii). The format, design and feel of books and the relative placement of words and pictures impact on the reader. In turn readers bring their own prior knowledge to the text. Furthermore, picture books are frequently aimed at both adult and young readers. Different layers of meaning may be revealed to both or explained by the adult enjoying the book with the child.

I have identified three main types of representation of nations in English and German picture books: the romantic-nostalgic approach; the realistic approach; and the humorous approach.

\section{THE ROMANTIC-NOSTALGIC APPROACH}

The romantic-nostalgic approach may relate to tourist attractions in towns, to the portrayal of town and countryside, or the remote spot far from civilisation. Examples of the first type are to be found in Ludwig Bemelmans' Madeline (1952) or Madeline in London (1962). Originally from Austria, Bemelmans emigrated to the USA where he produced a number of picture books in the 1950s and 1960s. In the 1990s they were re-issued and gained additional popularity after the box-office success of the film about the mildly mischievous anti-heroine and her convent school. Madeline embarks on a series of what Stephens describes in Language and Ideology in Children's Fiction as 'time-out' adventures, wending her way effortlessly between Paris and London. ${ }^{3}$

Madeline in London is like a visual diary, with images of Madeline posing tourist-style in front of many instantly familiar landmarks, sometimes with her fellow classmates. sometimes without. In true enlightenment tradition the new editor of Bemelmans' work prefaces the picture book 
with the words, presented as a block centred on the page:

Here is a list for those who may wish to identify the London scenes

Ludwig Bemelmans has pictured in this book.

Madeline's plane is flying over the HOUSES OF PARLIAMENT

BIG BEN is just above the nose WESTMINSTER ABBEY lies to the right and the river THAMES is in the background

Miss Clavel and her charges look for Madeline and Pepito in TRAFALGAR SQUARE beneath NELSON'S COLUMN

They also look near

WESTMINSTER ABBEY and ST JAMES PALACE

They rush past the DRURY LANE THEATRE near COVENT GARDEN

and finally find the two children and their horse in ST JAMES'S PARK .... "

This use of centred text and lack of conventional punctuation is presumably intended to make the information from the editor blend in better with the actual rhyming text itself, and detract attention from its primary educational purpose. Paradoxically, most of the information given is redundant, in that Bemelmans is portraying such well known sights. Although the work was first published in 1962, the red double-decker buses, Trafalgar Square, Westminster Abbey, the Tower of London, and Buckingham Palace still form the staple diet for most visitors to the metropolis. Yet the work is more than snapshots or postcards of locations and townscapes; it is almost a fairy-tale world of towers, flags and steeples, people in uniform, ceremony, all carefully choreographed.

The choreographing of images is reflected in the text, which is similarly orderly, squeezed into often illfitting rhyme schemes: 'The people below are stout and loyal, and those on the balcony mostly Royal'. The city is never seen as threatening or frightening. Despite the size of London, the nun in charge of the girls, who loses them, is confident that they will be found rapidly. Sure enough they are spotted standing in front of Buckingham Palace:

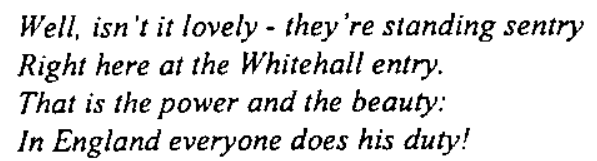

The tourist perspective is maintained even when the destination, England, is left behind. At the end of the story the girls and their teacher all head back by plane to Paris, and once on board are told: 'Fasten your seat belts, in half an hour / You will see the Eiffel Tower.' Like England, France is being portrayed through key landmarks which act as symbols of the country itself. ${ }^{5}$

Romanticisation and stereotypical images are also much in evidence in Phyllis Kraslovsky's The Cow that Fell in the Canal (1958), illustrated by Peter Spier's black and white line drawings, approximately half of which have colour washes over them. The story is set in the Netherlands, and features the adventures of a black and white Frisian cow called Hendrika in both town and countryside, beginning with the words: 'Hendrika was an unhappy cow. She lived on a farm in Holland, where it is very flat'. The action takes the reader along canals, past windmills, tulips in flower, barns and markets, past what she calls 'stair-cased roofs', bicycles, shops and streets and cheeses. Characters have Dutch names (Hendrika, Hofstra, Pieter) and there are Dutch-language signs in evidence, but the world of the cow, with which the child is invited to identify, is not so dissimilar to the world of an English cow. Hendrika is keen to see the 'exciting' things the horse talked about:

Poor unhappy Hendrika! She longed to see something besides the house, the barn and the windmill. Instead, she ate and ate and ate. And she grew fat, and then fatter, and then very very very fat. She grew so fat she could hardly move. She grew so fat she could hardly see! And then she fell in the canal.

Here begins what Stephens would term her 'time-out' adventure. As the narrator exclaims 'There was so much to see!'. The story ends with the cow safely back in her meadow: "Now she had so much to think about as she chewed the grass, looking so pretty in a coloured straw 
hat with streamers!' ln one short picture book almost every stereotype of the Netherlands is visible. The work provides an emblematic introduction to or reminder of "Holland' as it is promoted in tourist brochures."

The final English-language example of the romantic approach has a remote rural setting. The only Englishlanguage series which features a specific regional location is the 'Katie Morag' series, set on the north-west coast of Scotland, illustrated and written by Mairi Hedderwick. I would like to look in detail at Katie Morag Delivers the Mail (1984), and ask the question: How Scottish is it?

The names, the language and the local colour may at first seem very Scottish compared to most other Englishlanguage picture books. Yet although there are some Scottish characters, Mr and Mrs McColl, Mr MacMaster and Katie Morag herself and her brother Liam, some characters such as 'The Holiday People', The Lady Artist' and 'Mrs Bayview' have an Everyman-like quality. Neither is the language overly Scottish. After Katie has been thanked for her hard work delivering the mail her Grannie says: 'Och aye ... She's very good at sorting things out, is our Katie Morag', but 'Och aye' is part of every cliched picture of a Scotsperson, and the only line which would not be immediately understood by a Sassenach (the Scottish word for an English person) is when Grannie comments: 'Well, this is a fine hoorach you've got yourself into, Katie Morag'. This very limited inclusion of dialect is presumably in order that the book may appeal to as wide an audience as possible. Finally, some local colour is introduced, in the form of tartan skirts, a poster displayed in the post office advertising a ceilidh, and the hoarding advertising the Oban Times, but these are again very blatant examples of the Scotland outsiders may expect to see, rather than typical examples of the Scottish way of life in the 1980s.

The charm or appeal of the Scottishness is closely linked by the narrator to the distance from civilisation. Arguably the image of Scotland has as much to do with the ideal world of the reader as with the real world. The story begins, 'Wednesdays were always hectic on the Isle of Struay, for that was the day that the boat brought mail and provisions from the mainland'. Apart from this initial naming of the island and references to the Redburn Bridge, the universal appeal of the remote setting is reinforced by the illustrations, which have a timeless quality, with sunsets reminiscent of Turner's nineteenth century water-colours. The image of Grannie and Katie Morag on the tractor, Grannie's arm protectively round Katie, epitomises the mood created here. There are two people, seven sheep, two rabbits, a setting sun, one or two houses and mountains. beach and sea. What is interesting is that for many children this will probably be the only image of Scotland they know, since there are very few picture books set in urban, workingclass, multicultural Scotland.

Like the Katie Morag series, the Swiss 'Schellen-Ursli' trilogy, by two Romansch artists, author Selina Chönz and illustrator Alois Carigiet, has a remote rural setting. but here the similarity ends. Schellen-Ursli (first published 1945 in Romansch) is set in the mountains of the Swiss Engadine and portrays in verse form the centuries-old local tradition of ringing bells to drive out the winter. The region and its mountains are clearly recognisable. As Schultze-Kraft says:

here we see 'the idealised image of apre-industrial
Engadine peasant culture. The detailed factually
true-to-life representation of peasant cultural
artefacts, tools and homes, the peasant custom of
'Chalandamarz' which is at the heart of the story,
the use of the Romansch language-a peasant
language-and the systematic exclusion of
contemporary reality show that the choice of the
peasant culture as the central theme did not
happen by chance, but was indeed employed by
the twoauthors in a verydeliberatefashion.' (my
translation)

(1997, p.11).

The work was expressly written in Romansch in order to preserve as much of the local culture and atmosphere as possible, whereas Katie Morag only contains the odd snatch of dialect and does not give any detailed account of local customs. Schellen-Ursli has been seen as an emblem of Swiss national identity (see Schultze-Kraft, pp.14-16), with Graubünden, the canton in the south-east of Switzerland where it is set, understood as a microcosm of Switzerland as a whole.

Within the romantic-nostalgic works a wide range of 
cultural information may seem to be conveyed, but the emphasis tends to be on naming buildings, portraying cultural artefacts and the 'otherness' of customs, be it the ceilidh or the seasonal customs of the Engadine countryfolk.

\section{THE REALISTIC APPROACH}

Whereas the focus of the romantic, escapist approach is on the pre-industrial attractiveness of the countryside or city, the realistic approach adopts a more socially critical stance and metaphorically takes off the rose-tinted spectacles. Jil Paton Walsh's Babylon (1982) is not set in a specific town, but Dulcie, the young central figure, lives in a terraced house in a rougher, multicultural district of an industrial town in contemporary Britain. As the narrator says: 'Behind the houses where Dulcie lives there is a railway viaduct. Nothing grows in Dulcie's back yard, any time of the year, because the viaduct keeps out the sun'.

Implicitly, class, education and ethnicity play an important role in the story. Dulcie's friend David lives in a flat half way up a tower block. Even at the end of the twentieth century English picture books rarely include characters living in flats rather than houses; characters who have a limited income; children who attend state schools rather than the elite world of the private boarding school; or children from non-white families. Babylon is set in the world of junkyards, with old oildrums, a tramp, weeds, disused gasometers and exotic fruit and vegetables for sale on the local market stalls. The actual geographical location may be less clearly defined than that in the previous group of works, but it relates far more closely to the reality of life for the majority of children in urban Britain at the end of the twentieth century, and actually includes visual references to marginalised groups such as the homeless.

Another example of the realistic approach is to be found in Theresa Tomlinson's Little Stowaway (1997), which is based on the true story of John Robert Dryden, a twelveyear-old boy from Whitby (a fishing port on the North Sea coast of. England) who rescues a man from drowning. John's is in Stephens' terms a 'time-out' adventure. Tomlinson's carefully researched background of the lives and hardships of fishermen in days gone by is complemented by striking illustrations, many of which are instantly recognisable as representing Whitby, such as the view down across the pan-tiled roofs to the harbour. These water-colour illustrations owe a strong debt to the work of Frank Meadow Sutcliffe, a prominent nineteenth century photographer who worked in and around the town. Local colour abounds in both text and illustrations. The detailed descriptions of the clothes worn, the fish caught, and life on board ship locate the text in both time and place, and they have their counterparts in the visual realism. There are, for example, mentions of hymns and songs about catching fish, and a few bars of the music and words are reproduced alongside a picture of the fishermen sitting in the boat singing. In short, where Babylon gives insight into a particular class setting, Tomlinson offers a realistic view of a geographical location from a historical perspective.

\section{THE HUMOROUS APPROACH}

Whereas the romantic-nostalgic and the realistic works tend to emphasise the accuracy of many elements of the portrayal of geographical and cultural elements (even if there are animal protagonists), the humorous approach is more cavalier in this respect. I would like to examine a cartoon strip about someone many believe to be fictitious, FatherChristmas, and two anthropomorphic picture books.

Raymond Briggs' Father Christmas Goes on Holiday (1975) has the typical Briggsian comic-strip format, and its illustrated characters are closer to caricatures than photographic records. Like the work of socially critical German Expressionist artist Georg Grosz, Briggs draws attention to social anomalies and has a sympathy with the downtrodden. The speech bubbles contain fragments rather than sentences, and it is rare to find any descriptive passages. Capitalisation is used throughout to emphasise the difference between the comic-strip and the more traditional picture book. Father Christmas decides to visit 'FRANCE, THE LAND OF CULTURE, ART, CIVILIZATION, FOOD, WINE, SUN!" Once he has arrived in what he ironically exclaims is 'LA BELLE FRANCE' he is ecstatic because he has communicated successfully in French. For him France and the French are defiantly 'other'. The bread is 'BLOOMING FUNNY'; although offered 'POMMES SAUTEES' he groans to himself 'NO BLOOMING CHIPS' (a joke which only adults would understand) and finds the food 'BLOOMING EXPENSIVE!'. He is irritated about the 'BLOOMING 
FLIES!' and later suffers from 'BLOOMING DIARRHOEA'.

Like the images of France, the images of Scotland are based on stereotypes, but are highly self-reflexive and satirical in tone. Scotland is associated here with whisky, dramatic mountain peaks and mist-shrouded valleys. It is, of course, raining, and Father Christmas is greeted in the morning by a Loch Ness Monster-like creature popping its head out of the water. He meets a bagpiper who says cheerfully, 'I'M FAIR DRY, SIR!', referring of course not to the state of his clothes but to his desire to have an alcoholic drink. After enjoying haggis, swede and whisky (a deliberately exaggerated portrayal of the eating and drinking habits of the Scots) Father Christmas jumps into a cold lake for a swim, but promptly flees exclaiming: 'RAIN - COLD SHARKS! WHAT A COUNTRY'.

Father Christmas Goes on Holiday is not a simple travelogue, a guide to each country visited by the bearded old man, but a whimsical creation with humorous overtones in almost every cartoon image and speech bubble. Designed very much for both the older and the younger reader, the images of France and Scotland are charmingly disrespectful. Although Bhabha argues that national culture should not be seen as 'other', it is the humorous interweaving of the factual and the fantastic, and the expected and the unexpected images of otherness which challenge readers to reconsider their existing image of each nation. ${ }^{10}$

Humour may also be linked to an historical aspect of Europe. Both Brian Wildsmith's Le Tunnel (1993), and Hans Magnus Enzensberger's Esterhazy: Eine Hasengeschichte (1993, translated into English as Esterhazy, the Rabbit Prince) relate to key events in the history of Europe.

Le Tunnel, the Channel Tunnel, may be seen as a metaphor for efforts to bring Europe closer together. It is a tale of two moles, English Marcus and his French cousin Pierre, who are attempting to cross the English Channel. Each page is written in two languages and the book is in two halyes, with the French and English narrator each working from one end of the book towards each other, symbolising the building of the Channel Tunnel. The extra gimmick is the 'freshly dug mole-hole'.
Anthropomorphism does not exclude distinctive national paraphernalia and characteristics. One cover features a mole holding aloft the Union Jack, the other has the mole holding up the tricolore. We see the Cliffs of Dover and animals puzzling over how to reach the other side. There are talking moles, owis, rabbits and badgers. Once the animals encounter the 'monsters who live on the sea-bed' but will not allow the moles to pass there are marked differences between the strategies used by the English Marcus and French, and they persuade the monsters to let them past if they win respectively a game of darts and boules.

Le Tunnel may be seen as two versions of the same or a similar story, with intertextual references for the readers of both. It would be possible to keep reading and rereading the book, crossing and re-crossing the tunnel, if you keep tuming the book round to read each version of the tale. As Homi Bhabha says, it is important to see boundaries from both sides, and Le Tunnel offers readers a unique opportunity to do just this, to see both the French and the English perspective.

Just as the Channel Tunnel marks a boundary between Britain and mainline Europe, so the Berlin Wall marked the boundary between capitalist and communist Europe. Like Le Tunnel, Hans Magnus Enzensberger's Esterhazy (1993), illustrated by Irene Dische, also features animal protagonists and boundaries. One of the most momentous historical events in the history of Europe in the last part of the twentieth century is depicted, namely the fall of the Berlin Wall. The wonderfully idiosyncratic use of language depicts the adventures of the young rabbit Esterhazy as he searches Berlin for a suitably tall rabbit as a mate.

Boundaries are portrayed in carnivalesque fashion, be they the boundaries between the sexes or boundaries between two parts of the city. Irony, both verbal and visual, is built into every detail, even the name of the main character:

The full name of the youngest of all the Esterhazys was: His Most Distinguished Michael Paul Anton Maria Prince Esterhazy the 12,792nd of Saladina.

Prince Count of Carotstead, Count of Chicorystone, Lord of Parsleycastle, Leekingham 
and Turnipyard', but he is never referred to by his full name, firstly because it is solong, and secondly because rabbits are always known by their family name. " (my translation)

Esterhazy is searching for a wall because he is searching for a mate and has been told to look out for a large wall where he may find many rabbits. ${ }^{12}$ At first he has no luck:

So he kept hopping along, always following his nose, over the Kurfurstendamm [West Berlin's main shopping street] and past the Memorial Church. Now and then he bumped into a hydrant, a beggar or a sausage stand, always keeping to the edge of the kerb, because he was frightened that people would trample all over him. He listened, and sniffed, and came to the conclusion that there were lots and lots of sausage stands, buses and policemen - but no rabbits. ${ }^{13}$

After working for some time as an Osterhase (Easter Bunny) in a department store and beginning to despair of ever meeting a mate he eventually meets a young female rabbit called Mimi from the Tegeler Forest in Berlin. Once Esterhazy finally finds an 'endless, long, grey Wall' (my translation) with grass in front of it which smells wonderfully of rabbits, he settles down happily with Mimi, happily that is until the quality of their life is seriously reduced:

until one day, in the middle of the night, an incredible din started up. Hundreds of people were tramping around on the rabbits' meadow and all of them were cursing the Wall. They had got hammers and drills with them and started to bash down the Wall.

'What's up?' asked Esterhazy.

'The Wall's got to go!' the people cried.

The next evening the whole rabbit meadow was black with people. There were broken beer bottles lying all over the place and there were only a few bits left of the Wall. The people were beside themselves with joy, but Esterhazy could not work out why.

Esterhazy is a parable for our times, a mixture of politics, geography, history and fantasy. Does the reader learn about
Germany? Indirectly yes, because the reader has to read between the lines and provide the information which is implied. Interestingly, this anthropomorphic stance represents the Fall of the Wall as a mixed blessing, a view far closer to reality than the majority of the euphoric documentary reports which mushroomed in the heat of the moment.

In their carnivalesque delight in the playful, the adoption of different guises (particularly in the case of Father Christmas, but also in the case of Esterhazy) these humorous works are less overtly didactic than the romantic-nostalgic and the realistic works and offer readers more opportunities to construct their own reader/viewer positions.

\section{CONCLUSION}

Boundaries of different types, between the country and the town, between stereotypes and reality, between caricature and cultural insight, are much in evidence in the picture books surveyed, but they are the exceptions to the rule. It is rare within the world of these English and German picture books to find works in which images of specific European countries are highlighted. The three main approaches, the romantic-nostalgic, the realistic and the humorous are not mutually exclusive, but tend to diverge. Whereas the romantic-nostalgic approach offers insights into the more traditional aspects of nationhood and presents an unproblematic vision of rural life and a tourist's eye view of towns, the realistic approach shows a wider, less glossy cross-section of society in terms of class, ethnicity and work.

Paradoxically, it is through those images which are furthest removed from reality, the humorous images, that the reader may begin to approach what Homi Bhabha refers to as the fluidity of cultural boundaries, with the associated importance of the 'in-between' spaces, in which 'the meanings of cultural and political authority are negotiated' (1990, p. 4). The carnivalesque and playful interweaving of the world of the animated cartoon and a mythical figure, or of the concerns of animals and humans employ quirky, striking images. They challenge readers to take a critical view of the locations, people and events portrayed, to see Europe from both sides of the sleigh, both sides of the Channel, both sides of the Wall. Arguably it is these images which contribute most to heightening an understanding of other nations in Europe. 


\section{NOTES}

1. Given their awareness of the pseudo-scientific foundations of racial biology the authors asked readers to look at sixteen photographs of persons of different nationality and guess which is which. Needless to say, it is almost impossible to match all the faces and nationalities correctly. In their opposition to dogmatism and rigid categorisation the authors anticipate much of the work done later in the twentieth century on nationality.

2. The first European Community, the European Coal and Steel Community (ECSC) was established in 1951. The Treaty of Rome then established the European Economic Community (EEC) on 25 March 1957. As part of the enlargement of the Community, Denmark, Ireland and the United Kingdom became members on 1 January 1973. Out of this developed the European Union, which came into being on the signing of the Treaty of Maastricht on 7 February 1992.

3. Stephens differentiates between 'time-out' and 'transgressive' interrogative texts (1992:126), seeing the former as representing a certain escape from the restrictions of society and/or family whereas the latter is more radically critical of authority.

4. There are very few German-language picture books which are set in specific towns. Hans Gottanka's Wie die schöne Julia nach München kam has very specific places in Munich, from the town hall, Viktualienmarkt, the twin towers of the Frauenkirche, and various churches. The book forms part of a series of regional books which are now out of print, but set in over a dozen cities including Salzburg, Düsseldorf, Essen, Cologne and Würzburg. Although Hans Stützle's Geschichten vom Maikäfer Sepperl are set in Munich, relatively few of the illustrations relate to landmarks. Most feature the beetle and his friends.

5. Erika Mann, daughter of Nobel Prize winner Thomas Mann, wrote a number of children's books, many of which adopt the romantic-nostalgic approach and highlight key landmarks in the respective countries visited. Her 'Zugvögel' (Migrating birds) series, about a choir who travel round Europe, is based on Mann's own extensive travels and contains many references to specific well-known locations. The works have some illustrations.

6. In Peter Bichsel's short story about how America was discovered 'Amerika gibt es nicht' (America does not exist 1969) in the collection Kindergeschichten (Children's stories) the narrator suggests that many people retum from America recount tales of what they already knew, talking of skyscrapers, the Niagara Falls and New York. The suspicion is that they have not been away at all, but are just protecting Columbus, who has invented the continent. In Krasilovsky"s The cow that fell in the canal (1958) the reader might also suspect that the narrator and illustrator are merely recounting tales of a world they knew second-hand, since the story consists almost entirely of stereotypical images.

7. Otherpicture books which are set in Basel are Daniel und Domo Löw's Fasnachtsfieler (1996) and Vogel Gryff (1997), Peter Pauwels-Stöckli's Lenas erster Morgenstreich, (1999) and Ruth Wesenfels, Ein Schuggi sy Basel (1996). Images of Appenzell are to be found in Lilly Langenegger's Bläs und Zita (1999) and Albert Manser's Albertli (1987, already in its 8th edition).

8. Romansch is the fourth of Switzerland's four oflicial languages, following French, German and Italian in regard to numbers of speakers. Schellen-Ursli provided children with a book in their language, which is particularly important in an age in which English is gaining ground as the international language of communication throughout the world, to the detriment of many minority languages. See Johnson (1998, pp.4447) for an analysis of multilingualism in Switzerland.

9. In order to refresh his knowledge of French he watches a TV programme, where he is to be seen muttering in response to 'LA PLUME DE MA TANTE, LESSON NUMBER SIX', 'I COULD TELL WHAT TO DO WITH THE PLUME OF YOUR BLOOMING TANTE, MATE'.

10. In the work 'In einem Schloss in Schottland lebt einmal ein junges Gespenst' (In a castle in Scotland there once lived a young ghost) Franz Hohler portrays 
a Scotland with a red-headed man in a kilt, a man playing bagpipes, a castle, a ghost who is learning the art of frightening visitors to the castle, and as in Briggs' work there is a high degree of self-reflexivity. The features traditionally associated with Scotland are portrayed, but the narrator distances himself from this portrayal. Whereas ghosts are frightening, Hohler's ghost has to learn how to make people frightened of him. It is the playfulness which makes the text interrogative in Stephens' terms.

11. It is very hard to convey the playful inventiveness of each element of the names, each of which has linguistic connotations and despite their idiosyncratic construction have parallels in existing names. I have tried to convey something of this inventiveness.

12. The style of the illustrations has echoes of Roberto Innocenti's work Rose Blanche, which was translated into German as Rosa Weiß (1985). The latter used photographs of concentration camps and prisoners to create illustrations which whilst individual in style appeared very lifelike. Although the representations of buildings in Berlin and the Wall itself all also have an air of verisimilitude, the use of animals as the main characters in Esterhazy has an alienating effect.

13. The comment that there were no rabbits ever mentioned in the local papers is ironic. He says: 'Never anything but people! Fat people, thin people, natives and foreigners. Most of them had clothes on. It was only the women who often ran around without a shirt on and looked as if they were feeling the cold.' Here, as in Raymond Briggs' work, some of the humour is aimed explicitly at adults and the older reader.

\section{REFERENCES}

\section{Texts for Children}

Bemelmans, Ludwig (1996) Madeline. London, Scholastic [1952].

Bemelmans, Ludwig (1996) Madeline in London. London, Scholastic [1962].

Bichsel, Peter (1969) Kindergeschichten. Neuwied, Berlin, Luchterhand.
Briggs, Raymond (1998) Ethel \& Ernest: A True Story. London, Jonathan Cape.

Briggs, Raymond (1975) Father Christmas goes on Holiday. Harmondsworth, Puffin.

Chönz, Selina (1971) Uorsin. Ill. Alois Carigiet. Zurich, Lio Romontschan(Chur) [1945].

Chönz, Selina (1996) Schellen-Ursli. Ill. Alois Carigiet. Zurich, Orell Füssli [1945].

Chönz, Selina (1971) Flurina und das Wildvögelein. Ill. Alois Carigiet, Zurich.

Chönz, Selina (1971) Der grosse Schnee. Ill Alois Carigiet, Zurich.

Dische, Irene and Hans Magnus Enzensberger, (1993) Esterhazy: Eine Hasengeschichte. Aarau, Frankfurt am Main, Salzburg, Sauerländer.

Enzensberger, Hans Magnus (1993) Esterhazy: Eine Hasengeschichte. Ill. Irene Dische, Aarau, Frankfurt am Main, Salzburg, Sauerländer.

Essex County Council Education (1995) Traveller Alphabet. Cheimsford/Essex, Essex County Council Education.

Gottanka, Hans (nd) Wie die schöne Julia nach München kam. Ill Brigitte Würtz, Augsburg, Brigg.

Hedderwick, Mairi (1984) Katie Morag Delivers the Mail. London, Sydney, Toronto, Bodley Head.

Hohler, Franz (1979) In einem Schloss in Schottland lebte einmal ein junges Gespenst. Ill. Werner Maurer, Aarau, Frankfurt am Main, Salzburg, Sauerländer.

Innocenti, Roberto (1986) Rosa Weiß, Frankfurt am Main, Alibaba.

Krasilovsky, Phyllis (1992) The Cow that fell in the Canal. IIl. Peter Spier, London, Mammoth [1958].

Langenegger, Lilly (1999) Bläs und Zita. Appenzeller Verlag.

Löw, Daniel and Domo(1996) Fasnachtsfieber. Christoph Merian Verlag. 
Löw, Daniel and Domo (1997) Vogel Gryff. Christoph Merian Verlag.

Mann, Erika (1956) Die Zugvögel singen in Paris und Rom. Ill. Hans Schubel, Munich, Franz Schneider Verlag.

Mann, Erika (1963) Die Zugvögel: Sängerknaben auf abenteuerlicher Fahrt. Berlin, Darmstadt, Vienna, Deutsche Buch-Gemeinschaft [1959].

Manser, Albert (1987) Albertli. Atlantis Verlag pro juventute

O'Neill, Judith (1998) Leaving the Island. IIl. Lisa Kopper, Cambridge, CUP.

Pauwels-Stöckli, Peter (1999) Lenas erster Morgenstreich. Buchverlag Basler Zeitung.

Stützle, Hans (1988) Geschichten vom Maikäfer Sepperl. Ottweiler, Ottweiler Druckerei.

Tomlinson, Theresa (1997) Little Stowaway. Ill. Jane Browne, London, Random House.

Walsh, Jill Paton (1982) Babylon. Ill. Jennifer Northway, London, Andre Deutsch.

Wesenfels, Ruth (1996) Ein Schuggisy Basel. Buchverlag Basler Zeitung.

Wildsmith, Brian (1993) Le Tunnel/The Tunnel. Oxford, Oxford University Press.

\section{SECONDARY REFERENCES}

Baumgärtner, Alfred C. und Max Schmidt, Hrsg. (1991) Text und Illustration im Kinder- und Jugendbuch. Würzburg, Königshausen \& Neumann.

Bhabha, Homi (1990) Nation and Narration. London, New York, Routledge

Cianciolo, Patricia J. (1997) Picture Books for Children. Chicago and London, American Library Association.

Hollindale, Peter (1997) Signs of Childness in Children's Books. Stroud, Thimble Press.

Huxley, Julian S., Haddon A.C. and Carr-Saunders, A.M. (1935) We Europeans: A Survey of 'Racial'
Problems. Harmondsworth, Penguin.

Johnson, Sally (1998) Exploring the German Language. London, New York, Sydney, Auckland, Arnold.

Kaminski, Winfred (1989) Einführung in die Kinderund Jugendliteratur, Weinheim und München, Juventa.

Nodelman, Perry (1988) Words about Pictures: The Narrative Art of Children's Picture Books. Athens, London, University of Georgia Press.

Raecke, Renate, Hrsg. (1999) Kinder-und Jugendliteratur in Deutschland. München, Arbeitskreis für Jugendliteratur e.V.

Schultze-Kraft, Ofelia (1977) 'Eine Untersuchung zur Funktion der Darstellung von bäuerlicher Kultur und Brauchtum im schweizerischen Bilderbuch SchellenUrsli von Selina Chönz und Alois Carigiet', Volkskundliches Seminar der Universität Basel, Hausarbeit bei Prof. Dr. Burckhardt-Seebass.

Stephens, John (1992) Language and Ideology in Children's Fiction. London, Longman.

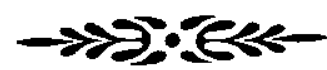

\section{BIOGRAPHICAL NOTE}

Susan Tebbutt is Senior Lecturer in German Studies and Head of German at the University of Bradford, England. Publications include her volume 'Gudrun Pausewang in context' (Lang 1994), the edited volume 'Sinti and Roma: Gypsies in German-Speaking Society and Literature' (Berghahn 1998) and numerous articles on Jugendliteratur and Gypsies, the two main areas of her research. She is preparing a volume on 100 years of German pacifist children's literature.

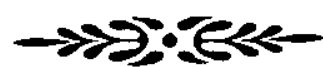

